\title{
Studies on the Prevalence of Sacculina Spp. Infestation in Portunus Sanguinolentus (Herbst, 1783) from Parangipettai Coastal Waters, Southeast Coast of India
}

\author{
S M Raffi*, V Elumalai, D Selvam, T V Suresh, M Pravinkumar, C Viswanathan and K Jaganathan \\ Centre of Advanced Study in Marine Biology, Annamalai University, Tamilnadu, India
}

\begin{abstract}
The presence of the external sacs on parasitic barnacles is the most unusual characteristic found in these genera. This barnacle belongs to genus rhizocephala that parasitizes crabs. Parasitization by sacculinids induces severe modifications in morphology, behavior and reproduction of their host (Brachyuran crabs: Portunus sanquinolentus). The present field study was carried out two landing center from Annankoil and Mudasalodai during January 2011December 2011. It was found that total catch of infected crab was $12.4 \%$ from Annankoil and Mudasalodai landing center. The frequently infected male and female crab ratio was $66.3 \%$ and $33.7 \%$. External parasites were found on crabs ranging from $56 \mathrm{~mm}$ to $88 \mathrm{~mm}$ in carapace width.
\end{abstract}

Keywords: Portunus sanquinolentus; Sacculina granifera

\section{Introduction}

Biological invasions and world-wide translocation of species pose great threat to the global environment and its after effects are creating severe havoc in marine ecosystems, often alters its biodiversity [1]. Introduction of exotic species or the abrupt proliferation of parasites in marine realm is a great menace the present day world is facing. Though the effects of some introductions are undetectable, but the introduction of some species may have dramatic ecological and economic impacts $[2,3]$. Parasitism is a biological trait that is defined predominantly in ecological terms [4]. Parasites constitutes nearly more than half of all biodiversity [5], but are least studied. Parasitic infestation and its associated diseases are the single most important factor threatening the fishery industry worldwide, particularly in the tropics [6]. Brachyuran crabs, especially those belongs to family portunidae forms an important constituent of marine fishery resources. Parasitic infestations caused by sacculinids in Brachyuran crabs is an havoc, that alters its morphology, physiology and reproductive pattern; which ultimately leads to population depletion of many crab species. Sacculina (Rhizocephalan) parasites are known to sterilize decapods hosts by altering their hormonal functions and generally cause abnormal host growth $[7,8]$. Rhizocephans cause castration, anecdysis, stunting and increased mortality to their crab hosts, and thus, can have direct and indirect effects on crustaceans fisheries $[9,10]$.

Indian marine ecosystem is extremely diverse blessed with an extensive coastline of 8,118 km, with an Exclusive Economic Zone (EEZ) of $2.02 \mathrm{mn}$ sq. $\mathrm{km}$ and a continental shelf area of $468,000 \mathrm{sq} \mathrm{km}$. India is bestowed with multispecies-multi sector marine fisheries resources, with total fish production of around 3.16 million tonnes [11]. Among the total marine fish production crustaceans occupies 16\% which are represented by shrimps, lobster and crabs, in which crabs fishery shared nearly of $9.6 \%$. It supports the sustenance fishery of appreciable importance, although it ranks third after shrimps and lobsters for their esteemed delicacy [12]. The marine crab fishery is supported mostly by the edible crabs belonging to the family Portunidae; represented mainly by Portunus pelagicus, P. sanguinolentus, Charybdis spp. etc. [13]. Among the portunids, three spotted crab, Portunus sanguinolentus is one of the commercially important species of crabs caught in moderate quantities all along the coast throughout the year and is generally caught as a bycatch in shrimp trawling.
Recent reports emphasized the shocking results of overwhelming predominance of sacculinid infestations in portunid crabs all along the southeast coast of India [14]. Pillai and Thirumilu [14] reported that the predominance was in the order of $P$. sanguinolentus followed by P. argentatus, Charybdis lucifera, C. feriatus and Podophthalmus vigil. Sacculina spp. is a typical crustacean parasite infested in shrimps and crabs. Sacculina belongs to the order, Rhizocephala, with special parasitic adaptations. They appear as a small tissue mass, projected out from the abdomen of crabs, which is termed as 'externa'. Parasitic barnacles (Cirripedia: Rhizocephala) are responsible for reducing the value of commercial crustaceans $[9,10,15]$. Larval rhizocephalan parasites infect mainly on decapods and the net effect is often a castration of both sexes of the host [16]. The rhizocephalan Sacculina has a marked effect on gonad development and growth; Sacculina infection may cause degeneration of the gonads in both male and female crabs and also modifies the secondary sexual characteristics in the male crab; resulting in the acquisition of female characteristics [17-19]. The wide prevalence of parasites noticed in a particular environment during a particular period of time might be attributed to change in the environmental parameters like water temperature, dissolved oxygen, salinity, $\mathrm{pH}$ etc., which may have an impact on the proliferation and survival of these parasites. The infection rates were seasonal for both sexes and were normally higher in the adult female population [20].

Investigations pertain to the prevalence of Sacculina infestations are often restricted mainly to temperate species and very few are reported from tropical waters. Pioneering works about the prevalence and infestation of Sacculina spp. are by Day [18]; Boschma [21-24]; Philips

*Corresponding author: Raffi SM, Faculty of Marine Sciences, Centre of Advanced Study in Marine Biology, Annamalai University, Tamilnadu-608 502, India, E-mail: raffi_cas@yahoo.com

Received January 04, 2013; Accepted January 07, 2013; Published January 09 2013

Citation: Raffi SM, Elumalai V, Selvam D, Suresh TV, Pravinkumar M, et al. (2012) Studies on the Prevalence of Sacculina Spp. Infestation in Portunus Sanguinolentus (Herbst, 1783) from Parangipettai Coastal Waters, Southeast Coast of India. J Biodivers Endanger Species 1:101. doi:10.4172/2332-2543.1000101

Copyright: @ 2012 Raffi SM, et al. This is an open-access article distributed under the terms of the Creative Commons Attribution License, which permits unrestricted use, distribution, and reproduction in any medium, provided the original author and source are credited. 
Citation: Raffi SM, Elumalai V, Selvam D, Suresh TV, Pravinkumar M, et al. (2012) Studies on the Prevalence of Sacculina Spp. Infestation in Portunus Sanguinolentus (Herbst, 1783) from Parangipettai Coastal Waters, Southeast Coast of India. J Biodivers Endanger Species 1:101. doi:10.4172/2332-2543.1000101

and Cannon [25]; O'Brien and Wyk [26]; Johnson et al. [27]; Potter et al. [28]; Shields [29]; Galil and Lutzen [30]; Galil and Innoncenti [31]; Thresher et al. [32]; Werner [33]; Innocenti et al. [34,35]; Chan [36]; Galil [37-40]. Most studies on species diversity and biology of the Sacculinidae are based on temperate regions [41,42]. Research on Sacculina species in the Asian waters has been conducted mainly in Japan by Lutzen and Takahasi [43], in Taiwan by Huang and Lutzen [44].

In India, only few published reports were available for the prevalence and histopathological analysis of Sacculina spp. And the noted works among them were by Nair and Gurumani [45]; George [46]; Pillai and Thirumilu [14]. Comparative assessment on proximate composition and nutritional value of infected and non-infected crab of $P$. sanguinolentus were carried out by Ramar [47]. A comprehensive report focusing on the seasonal prevalence of sacculinid infestation in Brachyuran crabs along the southeast coast of India is found wanting. In this backdrop, an attempt has been made in the present study to understand the season wise prevalence of Sacculina spp. in $P$. sanguinolentus landed in Parangipettai fishing harbour.

\section{Materials and Methods}

The edible Brachyuran crabs, P. sanguinolentus (Figure 1) were procured from trawl heaps landed at Mudasalodai landing centre of Parangipettai coast, Tamilnadu (Lat. $11^{\circ} 29^{\prime} \mathrm{N}$; Long. $79^{\circ} 46^{\circ} \mathrm{E}$ ) and the data were pooled up seasonally for a period of one year (January 2011December 2011). A total of 12,975 numbers of $P$. sanguinolentus were assessed among which 1,613 numbers were infested ones. Infected crabs were preserved in $10 \%$ formalin (tap water), formalin solution buffered with sodium borate (10 g/L solution) by Johnson et al. [27].

\section{Systematic Position}

Kingdom: Animalia

Phylum: Arthropoda

Class: Malacostraca

Order: Decapoda

Family: Portunidae

Genus: Portunus

Species: P. sanguinolentus

\section{Results}

A total of 12,975 specimens of $P$. sanguinolentus crabs were checked throughout the Study period of one year to find out the seasonal occurrence and host specificity of Sacculina infestation in Parangipettai coastal waters. Among the collected samples nearly, $12.4 \%$ of $P$. sanguinolentus crabs were infested by Sacculina castration. The infestation rate was varied among the seasons and also differs among the sexes of the host. The seasonal occurrence of sacculinid infestation was in the order that, Summer recorded the maximum (15.4\%), followed by Premonsoon (13.3\%), Postmonsoon (10.5\%) and Monsoon (7.4\%) respectively (Table1 and Figure 2). The rates of infestation were seasonal for both the sexes of $P$. sanguinolentus. The incidence of host specific prevalence were found more frequently on males (66.3\%) than the female crabs (33.7\%) (Table 2). Among the infected males, prevalence was maximum in Summer (67.4\%) followed by Premonsoon (67.1\%), Postmonsoon (64.7\%) and Monsoon (60.8\%)

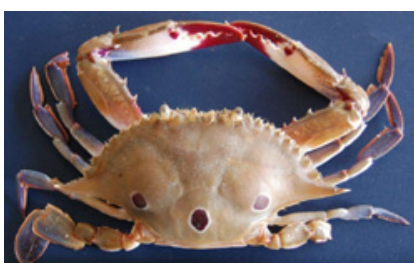

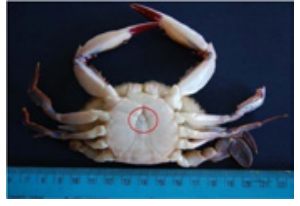

Noninfected male

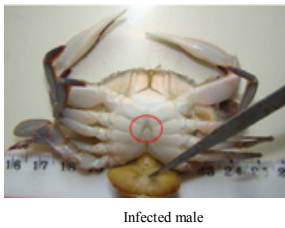

Figure 1: infected and non infected P.sanguinolentus (Herbst, 1783) crabs.

\begin{tabular}{|c|c|c|c|c|c|c|c|c|}
\hline \multirow[b]{2}{*}{$\begin{array}{c}\text { Infected } \\
\text { crab }\end{array}$} & \multicolumn{2}{|c|}{ Postmonsoon } & \multicolumn{2}{|c|}{ Summer } & \multicolumn{2}{|c|}{ Premonsoon } & \multicolumn{2}{|c|}{ Monsoon } \\
\hline & $\begin{array}{l}\text { Nos. of } \\
\text { crabs }\end{array}$ & $\begin{array}{l}\% \text { of } \\
\text { animal }\end{array}$ & $\begin{array}{l}\text { Nos. of } \\
\text { crabs }\end{array}$ & $\begin{array}{l}\% \text { of } \\
\text { animal }\end{array}$ & $\begin{array}{l}\text { Nos. of } \\
\text { crabs }\end{array}$ & $\begin{array}{l}\% \text { of } \\
\text { animal }\end{array}$ & $\begin{array}{l}\text { Nos. of } \\
\text { crabs }\end{array}$ & $\begin{array}{l}\% \text { of } \\
\text { animal }\end{array}$ \\
\hline Male & 220 & 64.7 & 290 & 67.4 & 500 & 67.1 & 59 & 60.8 \\
\hline Female & 120 & 35.3 & 140 & 33.7 & 245 & 32.9 & 38 & 39.2 \\
\hline Total & 340 & --- & 430 & --- & 745 & --- & 97 & --- \\
\hline
\end{tabular}

Table 1: Seasonal infestation rate of Sacculina spp. in P.sanguinolentus.

\begin{tabular}{|l|l|l|l|l|l|l|}
\hline \multicolumn{1}{c|}{ Crabs } & \multicolumn{1}{|c|}{$\begin{array}{c}\text { Postmon- } \\
\text { soon }\end{array}$} & Summer & $\begin{array}{c}\text { Premon- } \\
\text { soon }\end{array}$ & Monsoon & Total & \% \\
\hline $\begin{array}{l}\text { No. of } \\
\text { crabs } \\
\text { observed }\end{array}$ & 3250 & 2800 & 5600 & 1325 & 12975 & --- \\
\hline $\begin{array}{l}\text { Infected } \\
\text { male }\end{array}$ & 220 & 290 & 500 & 59 & 1069 & 66.30 \\
\hline $\begin{array}{l}\text { Infected } \\
\text { Female }\end{array}$ & 120 & 140 & 245 & 39 & 544 & 33.70 \\
\hline
\end{tabular}

Table 2: Sacculina spp. infestation rate in male and female crabs of $P$.sanguinolentus.

respectively. Among females, infestation rate lies from $32.9 \%$ to $39.2 \%$ among the seasons in such a fashion that; Monsoon season observed higher prevalence of $39.2 \%$ followed by Postmonsoon (35.3\%), Summer (33.7\%) and Premonsoon (32.9\%).

\section{Discussion}

The overall prevalence of Sacculina infestation in P. sanguinolentus found in this study is compared with works done elsewhere. Nearly, $12.4 \%$ of sacculinid's infestation was reported among the population of $P$. sanguinolentus which were checked for a period of one year. Among males, infestation prevalence was more in Summer; whereas as in the case of infected female crabs the prevalence was more in Monsoon. This clearly shows that infestations of sacculinid is irrespective of the seasons and are found throughout the year. The data were pooled up season wise that shows that infestation in males (66.3\%) are higher than the female crabs (33.7\%). Shrimp trawl activities reach its peak in all days of Premonsoon and part of days in Summer (due to trawl ban period) along the Parangipettai coast, so the availability of landed crabs were also on the higher end. This might be the reason for the higher prevalence of infested crabs during Summer and Premonsoon. 
Citation: Raffi SM, Elumalai V, Selvam D, Suresh TV, Pravinkumar M, et al. (2012) Studies on the Prevalence of Sacculina Spp. Infestation in Portunus Sanguinolentus (Herbst, 1783) from Parangipettai Coastal Waters, Southeast Coast of India. J Biodivers Endanger Species 1:101. doi:10.4172/2332-2543.1000101

Page 3 of 4

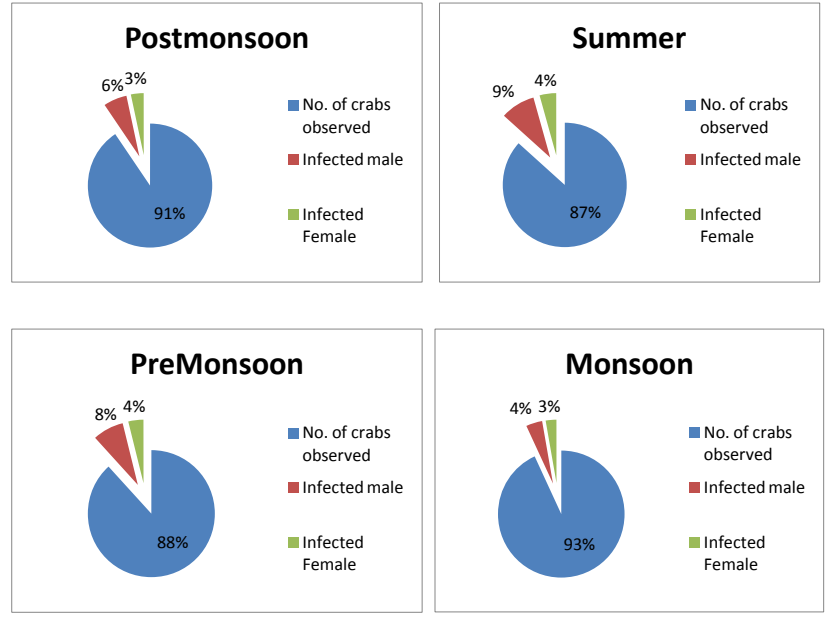

Figure 2: Prevalence of Sacculina spp in P.sanguinolentus recorded throughout the study period (2011).

Many reasons have been attributed to the temporal and spatial prevalence of sacculinid castration in marine crabs. George [48] observed that $20 \%$ of the examined crabs from Madras coast were infested by rhizocephalan parasite. According to Nair et al. [45], 169 out of 193 specimens of Portunus sanguinolentus had parasites of Sacculina. Grothers [49] suggested that infected hosts are more sluggish and are easily caught, and that passive fishing methods under estimate the true prevalence of parasites. Phang [50] accounted a prevalence range between $24 \%$ and $68 \%$ of Thompsonia sp. in P. pelagicus from Singapore and Perry (1984) pointed out that over 50\% of blue crabs from a single population in the Gulf of Mexico were infected with rhizocephalan parasite. Hawkes et al. [51] reported nearly $76 \%$ prevalence of the rhizocephalans in blue king crabs from Glacier Bay. Potter et al. [28] documented the higher occurrence of Sacculina granifera in the warmer months in Western Australia. Host density may affect prevalence of parasites and it was found that the locality with the highest abundance of hosts naturally had more parasitic infestation [52,53]. Hoeg [16] revealed that rhizocephalans are parasitic sterilizers and at high prevalences they must therefore exert a strong selection pressure on the host.

Pillai and Thirumilu [14] observed that more specimens of $P$. sanguinolentus were infected with Sacculina spp. when compared to other crabs in Chennai coast. They reported that Sacculina were first observed in crabs in the month of June, and later it was found to be prevalent in almost all the months. Only few authors investigated and discussed the parasitic infested rates and its host specificity of marine crabs. Pillai and Thomas (1972) observed that $12.2 \%$ of the total population of Portunus pelagicus was infested with the rhizocephalan parasite in the Gulf of Mannar. They suggested that infested parasite showed prefect female host specificity and nearly $28.1 \%$ of the female crabs were infested. Johnson et al. [27] analyzed that 50\% of the population of blue king crab, Paralithodes platypus were infected with rhizocephalan parasite. They revealed that both males and females were infected, but parasitic infection was strongly related to ovarian abnormalities.

Sumpton et al. [20] reported that the infection rates in Moreton Bay, Australia were seasonal for both sexes of $P$. pelagicus with higher prevalence in the adult female population in such a way that nearly $20 \%$ of adult females carried externae during the summer months. Werner
[33] explained that higher incidences of infestation were found more frequently on males than the females. Galil [40] suggested among the parasitic infected crabs, the percentage of males were found higher and with an increase in the prevalence of infestation. Based on the present investigation, it is evinced that Sacculina infestation exhibits no clear specificity on sex wise and seasonal wise, we found in considerable quantities round the year with slight increase in warmer months. From the present investigation, the higher prevalence of Sacculina spp. in $P$. sanguinolentus in Parangipettai coast pose an alarming situation and also put forth the query about the sustenance of crab fishery and its future stock; as this will pave way to the occurrence of parasitic castration that indeed negatively affects its reproductive capacity and future recruitment. This study will serve as a baseline platform for a detailed and thorough investigation aiming to understand the rate of sacculinid infestation in Brachyuran crabs and its effect in future stock of crab population.

\section{References}

1. Brandt van Driel TD (2010) Baseline study: Parasites of Carsinus maenas (L.) in its home range at Limfjorden, Denmark. Bachelor thesis submitted Department of Cell Biology and Comparative Zoology, Institute of Biology, University of Copenhagen, Denmark.

2. Parker IM, Simberloff D, Lonsdale WM, Goodell K, Wonham M, et al. (1999) Impact: toward a framework for understanding the ecological effects of invaders. Biol Invasi 1: 3-19.

3. Ruiz GM, Fofonoff P, Hines A, Grosholz ED (1999) Non-indigenous species as stressors in estuarine and marine communities: assessing invasion impacts and interactions. Limnol Oceanogr 44: 950-972.

4. Combes C (2001) Parasitism: the ecology and evolution of intimate interactions University of Chicago press, Chicago and London.

5. Diamond JM, Case TJ (1986) Communities of parasites with parasitic lifestyles. In: Community Ecology, Harper and Row, New York, USA

6. Schmidt GD, Roberts LS, Janovy J (2000) Foundations of parasitology. McGraw-Hill, Boston, USA.

7. Rubiliani C (1983) Action of a rhizocephalan on the genital activity of host male crabs: characterization of a parasitic secretion inhibiting spermatogenesis. Inter J Invert Repro 6: 137-147.

8. O'brien J (1984) Precocious Maturity of the Majid Crab, Pugettia producta Parasitized by the Rhizocephalan Barnacle, Heterosaccus californicus. Boi Bull 166: 384-395.

9. Lester RJG (1978) Marine parasites costly for fishermen. Aus Fish 37: 32-33.

10. Sloan NA (1984) Incidence and effects of parasitism by the rhizocephalan barnacle, Briarosaccus callosus Boschma, in the golden king crab, Lithodes aequispina Benedict, from deep fjords in northern British Columbia, Canada. J Exp Mar ecol 84:111-131.

11. CMFRI (2010) Annual Report 2009-2010. Central Marine Fisheries Research Institute, India.

12. Mohammed SA, Rahavan RP (2001) Mud crab-culture and fattening techniques, status and prospects. Sea Exp J 32: 25-29.

13. Rao P, Vedavyasa (1973) Proc. Symp. Liv Resources seas around India: 581 591.

14. Pillai SL, Thirumilu P (2010) Parasites of shrimps and crabs from the Chennai coast. Marine fisheries information service T\&E Ser 204: 19-20.

15. Basson M (1994) A preliminary investigation of the possible effects of rhizocephalan parasitism on the management of the crab fishery around South Georgia. CCAMLR Science 1: 175-192.

16. Hoeg JT (1995) The biology and life cycle of the rhizocephala (cirripedia). J Mar Biol Assoc UK 75: 517-550

17. Tattersall WM (1920) Sacculina and its effects on the host species. Rep Trans Manch Micro Soc 29-41.

18. Day JH (1935) The life-history of Sacculina. Quar Jour Micr Sci 77: 549-583.

19. Weng HT (1987) The parasitic barnacle, Sacculina granifera Boschma, 
Citation: Raffi SM, Elumalai V, Selvam D, Suresh TV, Pravinkumar M, et al. (2012) Studies on the Prevalence of Sacculina Spp. Infestation in Portunus Sanguinolentus (Herbst, 1783) from Parangipettai Coastal Waters, Southeast Coast of India. J Biodivers Endanger Species 1:101. doi:10.4172/2332-2543.1000101

affecting the commercial sand crab, Portunus pelagicus (L.), in populations from two different environments in Queensland. J Fish Dis 10: 221-227.

20. Sumpton WD, Potter MA, Smith GS (1994) Reproduction and growth of the commercial sand crab, Portunus pelaFgicus (L.) in Moreton Bay, Queensland. Asian Fish Scien 7: 103-113.

21. Boschma H (1937) The species of the genus Sacculina (crustacea rhizocephala). Zool Meded Mus Leiden 19: 187-328.

22. Boschma H (1950) Notes on Sacculinidae, chiefly in the collection of the United States National Museum. Zool Verh Mus Leiden 7: 1-55.

23. Boschma H (1955) The described species of the family Sacculinidae. Zool verh 27: $1-76$

24. Boschma H (1960) A rhizocephalan parasite of the crab Charybdis hoplites (Wood-Mason). Crus 1: 58-67.

25. Phillips WJ, Cannon LRG (1978) Ecological observations on the commercial sand crab, Portunus pelagicus (L.), and its parasite, Sacculina granifera Boschma, 1973 (Cirripedia: Rhizocephala). J Fish Dis 1: 137-149.

26. O'brien J, Van-wyk PM (1985) Effects of crustacean parasitic castrators (epicaridean isopods and rhizocephalan barnacles) on the growth of their crustacean hosts. Factors in Adult Growth 191-218.

27. Johnson PT, Macintosh PT, Somerton DA (1986) Rhizocephalan infecfion in blue king crabs, Paralithodes platypus, from Olga Bay Kodiak Island, Alaska. Fish Bull 84: 177-184.

28. Potter MA, Sumpton WD (1987) Sand crab research report : prepared for QFIRAC 6 October 1987 / by M.A. Potter and W.D. Sumpton, Fisheries research branch, Queensland Department of Primary Industries, Australia.

29. Shields JD (1992) Parasites and symbionts of the crab Portunus pelagicus from Moreton Bay, Eastern Australia. J Crust Biol 12: 94-100.

30. Galil BS, Lützen J (1995) Biological observations on Heterosaccus dollfus boschma (Cirripedia: Rhizocephala), a parasite of Charybdis longicollis leene (decapoda: brachyura), a Lessepsian migrant to the Mediterranean. J Crus biol 15: 659-670.

31. Galil BS, Innocenti G (1999) Notes on the population structure of the portunid crab Charybdis longicollis Leene, parasitized by the rhizocephalan Heterosaccus dollfusi Boschma, off the Mediterranean coast of Israel. Bull Mar Sci 64: 451-463.

32. Thresher RE, Werner M, Hoeg JT, Svane I, Glenner H, et al. (2000) Developing the options for managing marine pests: specificity trials on the parasitic castrator, Sacculina carcini, against the European crab, Carcinus maenas, and related species. J Exp Mar Biol Ecol 254: 37-51.

33. Werner M (2001) Prevalence of the parasite Sacculina carcini Thompson 1836 (crustacea, rhizocephala) on its host crab Carcinus maenas (L.) on the west coast of Sweden. Ophel 55: 101-110.

34. Innocenti G, Vannini M, Galil BS (1998) Notes on the behaviour of the portunid crab Charybdis longicollis Leene parasitized by the rhizocephalan Heterosaccus dollfusi Boschma. J Nat His 32: 1577-1585.

35. Innocenti G, Pinter N, Galil BS (2003) Observations on the agonistic behavio of the swimming crab Charybdis longicollis Leene infected by the rhizocephalan barnacle Heterosaccus dollfusi Boschma. Can J Zoo 81: 173-176.
36. Chan KKB (2004) First record of the parasitic barnacle Sacculina scabra Boschma, 1931 (crustacea: Cirripedia: Rhizocephala) infecting the shallow water swimming crab Charybdis truncate. T R Bull Zool 52: 449-453.

37. Galil BS (1986) Red Sea decapods along the Mediterranean coast of Israel: ecology and distribution. In Environmental Quality and Ecosystem Stability, Ramat Gan, Bar- Ilan University Press, Israel 179-183.

38. Galil BS (2000) A sea under siege alien species in the Mediterranean. Biol Inva 2: $177-186$.

39. Galil BS (2004) Exotic species in the Mediterranean Sea and pathways of invasion. The Effects of Human Transport on Ecosystems, Royal Irish Academy $1-14$.

40. Innocenti G, Galil BS (2007) Modus vivendi: invasive host/parasite relationsCharybdis longicollis Leene, 1938 (Brachyura: Portunidae) and Heterosaccus dollfusi Boschma, 1960 (Rhizocephala: Sacculinidae). Hydro 590: 95-101.

41. Oksnebjerg B (2000) The rhizocephala (crustacea: cirripedia) of the Mediterranean and Black seas: taxonomy, biogeography, and ecology. Israe J Zoo 46: 1-102.

42. Walker G (2001) Introduction to the rhizocephala (crustacea: cirripedia). J Morphol 249: 1-8.

43. Lutzen J, Takahashi T (1997) Sacculina polygenea, a new species of rhizocephalan (Cirripedia: Rhizocephala) from Japan, parasitic on the intertida crab Hemigrapsus sanguineus (De Haan, 1835) (Decapoda: Brachyura: Grapsidae). Crus Res 26: 103-108.

44. Huang JF, Lutzen J (1998) Rhizocephalans (crustacea: cirripedia) from Taiwan. $\mathrm{J}$ Nat His 32: 1319-1337.

45. Nair NB, Gurumani ON (1956) On the occurrence of the three Sacculina parasitizing species in the edible crab Neptunus sanguinolentus. J Bombay Nat Hist 53: 730-732.

46. George Al (1959) Heterosaccus ruginosus, A rhizocephalan parasite of the crab Neptunus sanguinolentus. J Zoo Soc Ind 11: 171-204.

47. Ramar P (1991) The effect of rhizocephalan parasite (Sacculina) on crabs M.Sc. dissertation, CAS in Marine Biology, Annamalai University, India.

48. George Al (1943) Proc. 30th Indian Sci. Congress, India 3: 58.

49. Crothers JH (1968) The biology of the shore crab Carcinus maenas (L.) 2. The life of the adult crab. Field studies 2: 579-614.

50. Phang VPE (1975) Studies on Thompsonia sp. a parasite of the edible swimming crab Portunus pelagicus. Malay Nat J 29: 90-98.

51. Hawkes CR, Meyers TR, Shirley TC (1987) Growth of Alaskan blue king crabs, Paralithodes platypus (Brandt), parasitized by the rhizocephalan Briarosaccus callosus Boschma. Crus 52: 78-84.

52. Blower SM, Roughgarder J (1989) Parasites detect host spatial pattern and density: a field experimental analysis. Oecolgia 78: 138-141.

53. Rohde K (1993) Ecology of marine parasites : an introduction to marine parasitology. Wallingford $\mathrm{CAB}$, international, Australia. 